\title{
Investigation on Direct-to-Blister Smelting of Chalcocite via Thermodynamics and Experiment
}

\author{
Shiwei Zhou ${ }^{1,2}$, Xiang Guo ${ }^{1,2}$, Bo Tian ${ }^{1,2}$, Bo Li ${ }^{1,2}$ and Yonggang Wei ${ }^{1,2, *}$ \\ 1 State Key Laboratory of Complex Nonferrous Metal Resources Clean Utilization, Kunming University of \\ Science and Technology, Kunming 650093, China; swzhou90@126.com (S.Z.); gxyy0707@163.com (X.G.); \\ tianbo9908@163.com (B.T.); libokmust@163.com (B.L.) \\ 2 Faculty of Metallurgical and Energy Engineering, Kunming University of Science and Technology, \\ Kunming 650093, China \\ * Correspondence: weiygcp@kust.edu.cn; Tel.: +86-871-6518-5638
}

Citation: Zhou, S.; Guo, X.; Tian, B.; Li, B.; Wei, Y. Investigation on Direct-to-Blister Smelting of Chalcocite via Thermodynamics and Experiment. Metals 2021, 11, 19 https://dx.doi.org/10.3390/ met11010019

Received: 2 November 2020 Accepted: 21 December 2020 Published: 24 December 2020

Publisher's Note: MDPI stays neutral with regard to jurisdictional claims in published maps and institutional affiliations.

Copyright: (C) 2020 by the authors. Licensee MDPI, Basel, Switzerland. This article is an open access article distributed under the terms and conditions of the Creative Commons Attribution (CC BY) license (https: / / creativecommons.org / licenses/by/4.0/).

\begin{abstract}
Direct-to-blister copper smelting is an important smelting process due to its short process, low energy consumption and environmental protection. This study attempts to use high-grade chalcocite as the raw material for direct-to-blister smelting to realize the production of blister in a single furnace. The issues and required conditions of the process are analyzed from the thermodynamics viewpoint. By adjusting the ratio of iron to silica, the flux content and other raw material components, the direct-to-blister smelting is finally realized in a lab-scale. The copper recovery is over $82 \%$, and the copper loss in the slag is analyzed in detail. This work offers a theoretical guidance for the short-process smelting of high-grade copper concentrate.
\end{abstract}

Keywords: chalcocite; direct-to-blister smelting; thermodynamics

\section{Introduction}

With the rapid development of technology, copper smelting equipment had improved in terms of strengthening process, mechanization scale and production scale. However, the large-scale production technology of copper, which consists of smelting and converting processes, had not changed much in the past 100 years. Due to the insufficient process simplification, it not only consumed a lot of fuel, but also caused low-altitude pollution of $\mathrm{SO}_{2}$ [1,2]. Thus, major technological reform was made in copper smelting technology [3], and the direct-to-blister (DB) copper production in a single furnace came into being. It is in line with the development direction of the green metallurgical industry, due to its short process, high productivity, and less $\mathrm{SO}_{2}$ pollution $[4,5]$.

The DB copper smelting technology combines the smelting and converting into one step to complete the production of blister in a single furnace, making the smelting process strengthened [6,7]. For direct smelting process, related researchers [1,8-13] studied the thermodynamic calculation, equilibrium system and slag type, especially the issue of copper solubility in slag. Compared with the conventional iron silicate slag, the ferrouscalcium silicate slag has the advantages of expanded liquid area and lower copper content in the slag for DB smelting [14,15]. Yazawa et al. [16-19] researched the thermodynamic problems of copper smelting and the solubility of copper in slag. Chen et al. [20,21] theoretically analyzed the feasibility of using high-silicon and low-iron copper concentrate as raw materials for direct copper smelting, and it was also proved that adding proper amounts of $\mathrm{CaO}$ and $\mathrm{SiO}_{2}$ had the advantages of low slag viscosity and low dissolved copper content in slag. Taskinen et al. [22,23] explained the benefits of adding a small amount of $\mathrm{CaO}$ to the iron silicate slag during the DB smelting. Therefore, the DB smelting can be achieved under the conditions of reasonable raw materials, slag composition, temperature and so on. It made the three copper plants (Glogów II in Poland, Olympic Dam in Australia, Chingola in Zambia) adopt the DB smelting technology so far. 
High copper content in slag is a critical factor hindering the development of DB copper smelting. This requires reasonable raw material components, slag components, smelting temperature and other smelting parameters. Thus, the high-grade chalcocite was used as the raw material in present. The DB copper smelting process was analyzed with the help of thermodynamic calculation. Based on the results of theoretical analysis, the raw materials and slag compositions for DB copper smelting were adjusted, and the smelting parameters were also obtained. Combined with experimental verification, the DB copper smelting of chalcocite was realized in a lab-scale. The results obtained in this paper could provide a treatment idea for smelting high-grade copper concentrates with a clean and short process.

\section{Materials and Methods}

\subsection{Materials}

The chalcocite was obtained from the local smelter, and the chemical analysis results were listed in Table 1, which shows that the $\mathrm{Cu}$ content in minerals is $53.55 \mathrm{wt}$ \%. The $\mathrm{Fe} / \mathrm{SiO}_{2}$ ratio in chalcocite was only 0.29 , indicating that it belongs to low-iron high-silica ore. For increasing the $\mathrm{Fe} / \mathrm{SiO}_{2}$ ratio, the chalcopyrite was used to mix with chalcocite. The compositions of chalcopyrite were also listed in Table 1, and the $\mathrm{Fe} / \mathrm{SiO}_{2}$ ratio was 5.80.

The calcium oxide $(\mathrm{CaO})$ used in the experiment is of chemical grade.

Table 1. The chemical analysis results of minerals.

\begin{tabular}{ccccccccc}
\hline \multirow{2}{*}{ Mineral } & \multicolumn{8}{c}{ Concentrate Composition (wt.\%) } \\
\cline { 2 - 8 } & $\mathbf{C u}$ & $\mathbf{F e}$ & $\mathbf{S}$ & $\mathbf{S i O}_{\mathbf{2}}$ & $\mathbf{C a O}$ & $\mathbf{M g O}$ & $\mathbf{A l}_{\mathbf{2}} \mathbf{O}_{\mathbf{3}}$ & $\mathbf{F e} / \mathbf{S i O}_{\mathbf{2}}$ \\
\hline Chalcocite & 53.55 & 4.23 & 15.26 & 14.37 & 0.26 & 1.15 & 3.55 & 0.29 \\
Chalcopyrite & 30.00 & 29.00 & 30.00 & 5.00 & 0.50 & 0.48 & 0.50 & 5.80 \\
\hline
\end{tabular}

\subsection{Methods}

Based on the ore composition, the equilibrium module of Factsage software (8.0 version, ThermFact LTD, Montréal, QC, Canada) was used to calculate the equilibrium phase evolution of raw material $\left(1 \mathrm{t}\right.$ of ore coupled with flux) at different temperature $\left(1100 \sim 1350{ }^{\circ} \mathrm{C}\right)$ during smelting; and then the calculated slag viscosity could be obtained from the viscosity module [24].

The experimental verification was performed in a lab-scale vertical tube electricresistance furnace (Mita Electric Furnace Co., Ltd, Xiangtan, China), and the schematic diagram of experimental device was shown in Figure 1. Firstly, the weighed empty crucible was placed in the resistance furnace, and the lance (KPSX Chemical porcelain factory, Tangshan, China) was inserted into the constant-temperature zone of the furnace from the top of the furnace and heated up to $130{ }^{\circ} \mathrm{C}$ for $30 \mathrm{~min}$ at the rate of $10^{\circ} \mathrm{C} / \mathrm{min}$. Then, $80 \mathrm{~g}$ of mixed raw material was put into the corundum crucible with the feeder. After holding for $30 \mathrm{~min}$, the oxygen-enriched air was injected inside the melt. After injection, the lance was taken out of the furnace, and the melt was kept at a constant temperature of $1300{ }^{\circ} \mathrm{C}$ for a setting time and then cooled with the furnace.

The crucible with sample was weighed and subjected to separate the blister copper and slag. The slag amount and copper recovery were calculated using Equations (1) and (2):

$$
\begin{aligned}
& M_{4}=M_{1}-M_{2}-M_{3} \\
& R=\frac{M_{3} \times W_{3}}{M_{0} \times W_{0}} \times 100 \%
\end{aligned}
$$

where $M_{1}, M_{2}, M_{3}, M_{4}$ represent the crucible mass with sample, empty crucible mass, blister mass and slag amount, respectively; $R$ represents the copper recovery; $M_{0}, W_{0}$ are the raw material weight and copper content in the ore, respectively; $W_{3}$ is the copper content in the blister. 
The thermodynamic theory calculation adopts the Factsage software. The microstructure and phase distribution were analyzed by Electro-Probe Microanalysis (EPMA, JEOL, JXA 8230, Tokyo, Japan).

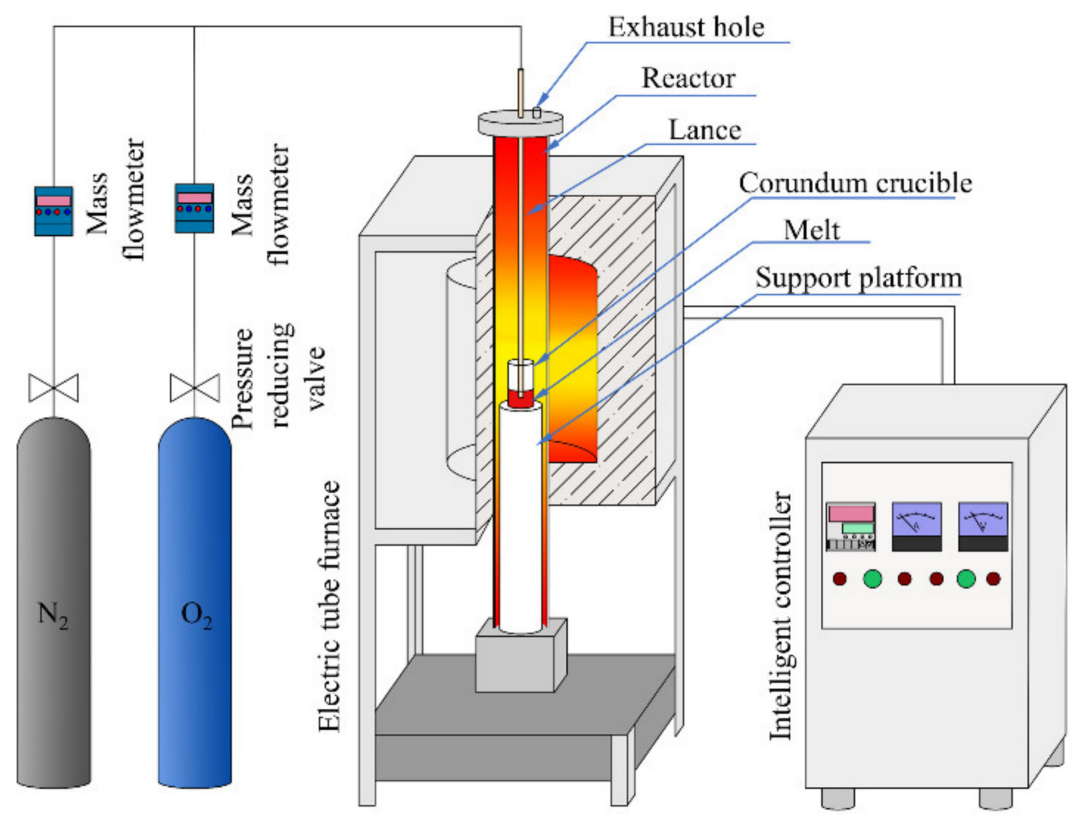

Figure 1. Schematic diagram of experimental device.

\section{Results and Discussion}

\subsection{Thermodynamic Analysis}

During the DB copper smelting process, the main reactions may occur as follows $[3,6,22]$ :

$$
\begin{aligned}
& \mathrm{FeS}_{2}=\mathrm{FeS}+\frac{1}{2} S_{2} \\
& \mathrm{CuFeS}_{2}=\mathrm{FeS}+\frac{1}{2} \mathrm{Cu}_{2} \mathrm{~S}+\frac{1}{4} S_{2} \\
& \mathrm{~S}_{2}+2 \mathrm{O}_{2}=2 \mathrm{SO}_{2} \\
& \mathrm{FeS}+\frac{3}{2} \mathrm{O}_{2}=\mathrm{FeO}+\mathrm{SO}_{2} \\
& \mathrm{FeO}+\frac{1}{2} \mathrm{SiO}_{2}=\frac{1}{2} \mathrm{Fe}_{2} \mathrm{SiO}_{4} \\
& \mathrm{FeO}+\frac{1}{6} \mathrm{O}_{2}=\frac{1}{3} \mathrm{Fe}_{3} \mathrm{O}_{4} \\
& \mathrm{FeS}+\frac{5}{3} \mathrm{O}_{2}=\frac{1}{3} \mathrm{Fe}_{3} \mathrm{O}_{4}+\mathrm{SO}_{2} \\
& \mathrm{FeS}+3 \mathrm{Fe}_{3} \mathrm{O}_{4}+5 \mathrm{SiO}_{2}=5\left(2 \mathrm{FeO} \cdot \mathrm{SiO}_{2}\right)+\mathrm{SO}_{2} \\
& \mathrm{Cu}_{2} \mathrm{~S}+\frac{3}{2} \mathrm{O}_{2}=\mathrm{Cu}_{2} \mathrm{O}+\mathrm{FeO} \\
& \mathrm{FeS}+\mathrm{Cu}_{2} \mathrm{O}=\mathrm{FeO}+\mathrm{Cu}_{2} \mathrm{~S} \\
& \mathrm{Cu}_{2} \mathrm{~S}+2 \mathrm{Cu}_{2} \mathrm{O}=6 \mathrm{Cu}+\mathrm{SO}_{2}
\end{aligned}
$$

The relationship between the standard Gibbs free energy and the temperature of each reaction was calculated as shown in Figure 2. At the smelting temperature ranges of $1100 \sim 1350{ }^{\circ} \mathrm{C}$, the standard Gibbs free energy of each reaction reflects negative value, indicating that the reactions can proceed in the positive direction. 
Under standard conditions, $\mathrm{FeS}_{2}$ and $\mathrm{CuFeS}_{2}$ began to decompose at $719{ }^{\circ} \mathrm{C}$ and $875^{\circ} \mathrm{C}$, respectively. With the increasing temperature, the $\mathrm{FeS}$ and $\mathrm{S}_{2}$ are oxidized to form $\mathrm{FeO}, \mathrm{Fe}_{3} \mathrm{O}_{4}$ and $\mathrm{SO}_{2}$ (Equations (6), (8) and (9)). Additionally, the iron oxides combine with silica to form slag at high temperature (Equations (7) and (10)). From a thermodynamic viewpoint, iron sulfide oxidizes in preference to copper sulfide. When the concentration of $\mathrm{FeS}$ was reduced to a certain value (the concentration of $\mathrm{Cu}_{2} \mathrm{~S}$ in the melt was about 25,000 to 7800 times that of $\mathrm{FeS}$ ) [3], $\mathrm{Cu}_{2} \mathrm{~S}$ began to oxidize to form $\mathrm{Cu}_{2} \mathrm{O}$. Moreover, the FeS coexists with $\mathrm{Cu}_{2} \mathrm{O}$, Equation (12) would occur to form $\mathrm{Cu}_{2} \mathrm{~S}$, and $\mathrm{Cu}_{2} \mathrm{O}$ reacted with $\mathrm{Cu}_{2} \mathrm{~S}$ to form blister copper (Equation (13)).

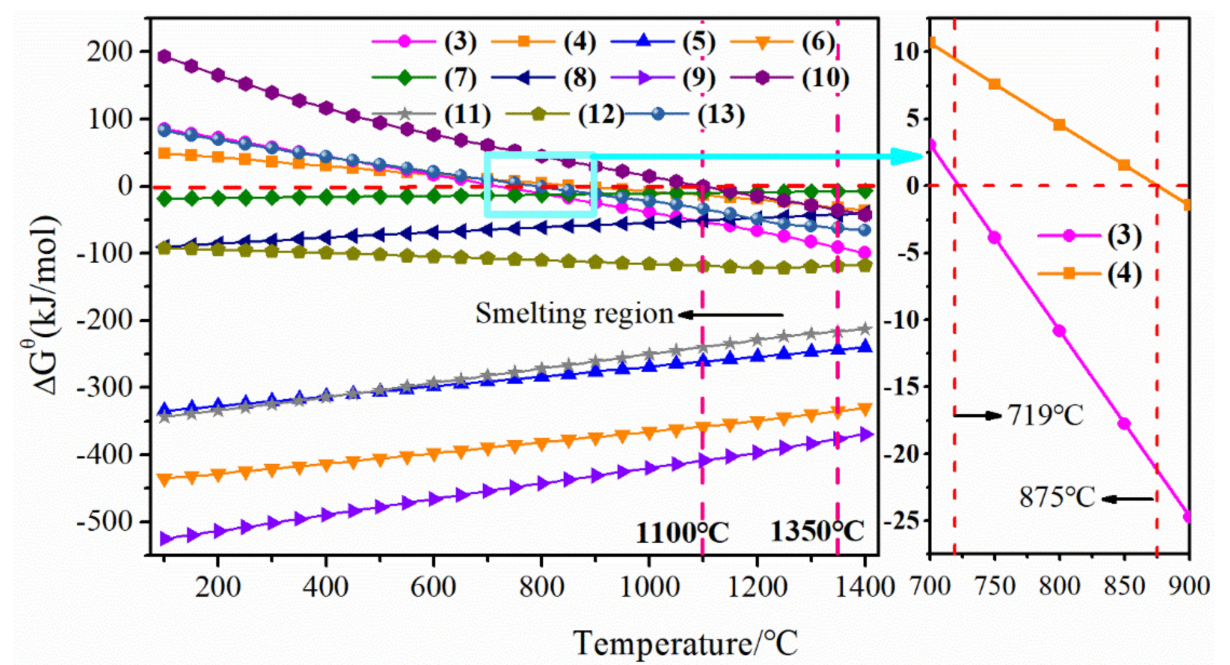

Figure 2. Standard Gibbs free energy of Reactions 3 to 13.

\subsection{Slag Analysis}

Based on the principle of minimum Gibbs free energy, the phase transformation in the chalcocite smelting process for blister production is theoretically calculated, as shown in Figure 3. In the low temperature section $\left(\mathrm{T}<1200^{\circ} \mathrm{C}\right)$, the melt composition is complex, including spinel, silica, cordierite, orthopyroxene, anorthite, liquid slag and copper. As the temperature rises $\left(\mathrm{T}>1200{ }^{\circ} \mathrm{C}\right)$, the spinel, orthopyroxene and anorthite phase gradually dissolved into the slag phase, causing the slag liquid content to increase. Parts of silica could be observed in the melt as temperature increases to $1300{ }^{\circ} \mathrm{C}$. This finding might be attributed to the low $\mathrm{Fe} / \mathrm{SiO}_{2}$ ratio (0.29); excessive silica exists in the melt in the form of free state. Silica in the melt would form a complex network structure with silicon-oxygen tetrahedrons as structural units, leading to an increase in viscosity. The above analysis results indicate that it is theoretically unfeasible to use chalcocite as raw ore for blister production in a single furnace due to the unreasonable of slag property.

By increasing the cation in the melt, the free silica can be converted into silicate, thereby destroying the network silicate structure. Combined with the actual production situation, $\mathrm{Fe}^{2+}$ and $\mathrm{Ca}^{2+}$ are ideal cations. An increase in the ratio of iron to silica would increase the activity of magnetite in the slag, and the magnetite phase might be precipitated as a result. Therefore, the amount of iron ions should be reasonably controlled.

Chalcopyrite was used to increase the raw ore $\mathrm{Fe} / \mathrm{SiO}_{2}$ ratio to 0.6 , and the compositions of mixed ore are listed in Table 2. Figure 4 shows the equilibrium amounts of species as a function of temperature. When the temperature is higher than $1200{ }^{\circ} \mathrm{C}$, only two phases remain in the melt, namely the blister copper and the slag liquid phase. Compared with Figure 3, the silica phase disappeared, which is mainly due to the combination of silica and iron oxide to form fayalitic slag. The purpose of DB copper smelting is to convert copper concentrate into blister copper and slag liquid phase, and then separate them by their density difference. The physical and chemical properties of molten slag affect the smelting process, and slag fluidity well is a prerequisite for slag-copper separation. Based 
on the production experience, the copper slag with a good fluidity when the viscosity is less than $1 \mathrm{~Pa} \mathrm{~s}$, and metallic copper sedimentation and separation from the slag are more thorough. Theoretical calculation indicates that the viscosity of the slag phase in Figure 4 is approximately $2.69 \mathrm{~Pa} \cdot \mathrm{s}$ at $1300{ }^{\circ} \mathrm{C}$, demonstrating that the DB copper smelting process could not proceed smoothly. Thus, the property of slag needs to be further adjusted for promoting smelting.

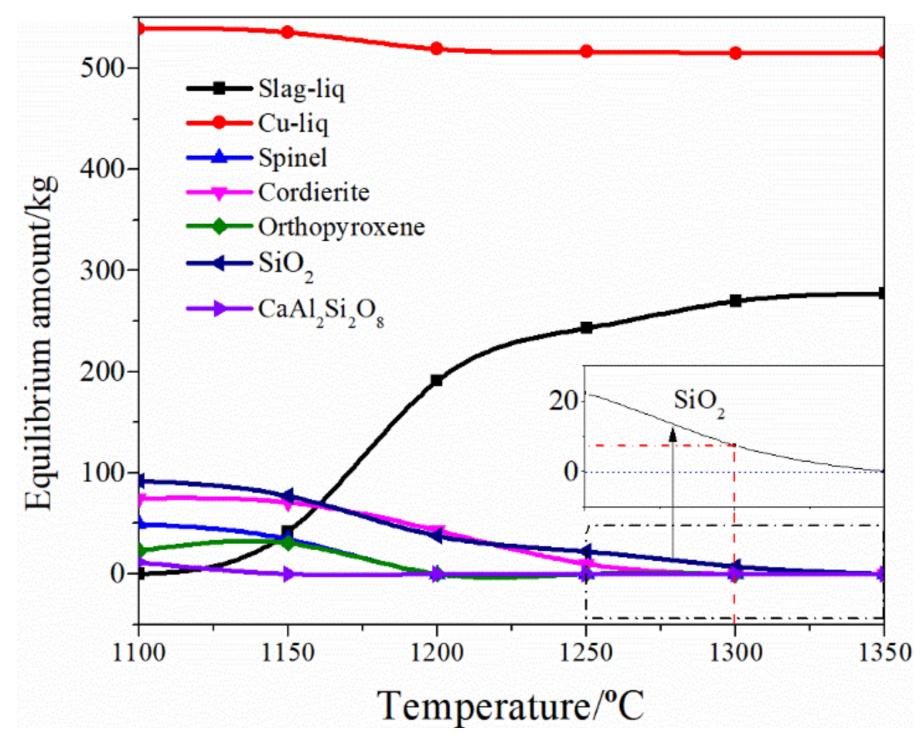

Figure 3. Effect of temperature on the equilibrium amounts of species for DB smelting of chalcocite.

Table 2. The chemical analysis of mixed ore with $\mathrm{Fe} / \mathrm{SiO}_{2}$ ratio 0.6.

\begin{tabular}{cccccccc}
\hline $\mathbf{C u}$ & $\mathrm{Fe}$ & $\mathrm{S}$ & $\mathrm{SiO}_{\mathbf{2}}$ & $\mathrm{CaO}$ & $\mathrm{MgO}$ & $\mathbf{A l}_{\mathbf{2}} \mathbf{O}_{\mathbf{3}}$ & $\mathbf{F e} / \mathrm{SiO}_{\mathbf{2}}$ \\
\hline 50.15 & 7.81 & 17.39 & 13.01 & 0.29 & 1.05 & 3.11 & 0.6 \\
\hline
\end{tabular}

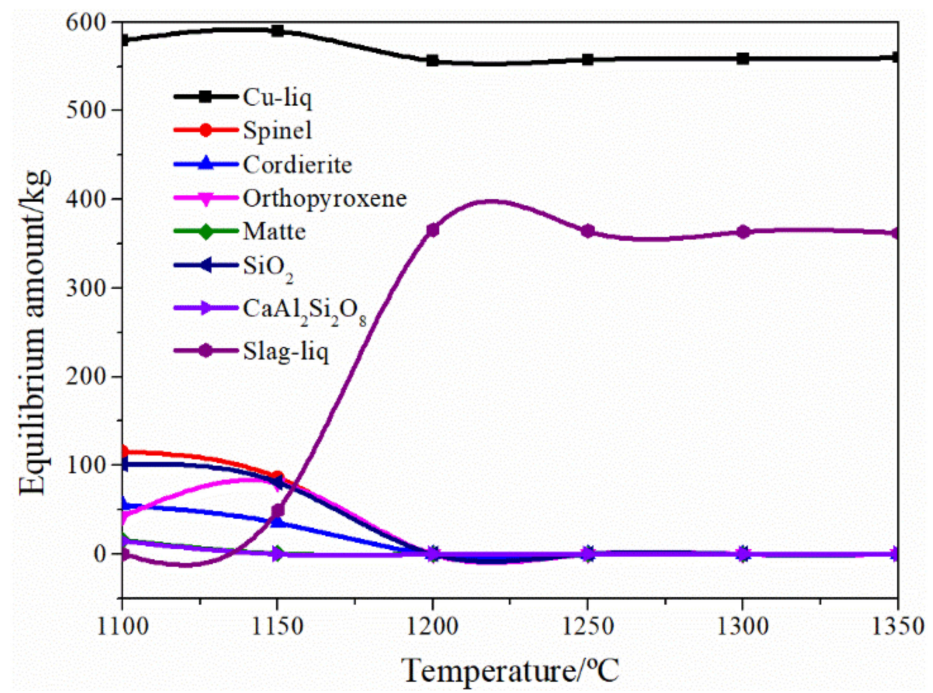

Figure 4. Effect of temperature on the equilibrium amounts of species for DB (direct-to-blister) smelting of mixed ore.

Adding $\mathrm{CaO}$ would increase the alkalinity of slag, and alkaline ions could promote the destruction of silicate network structure. For the slag composition with iron-silica ratio of 0.6 , the slag viscosity decreases with increasing $\mathrm{CaO}$ content, as shown in Figure 5 . When the addition of $\mathrm{CaO}$ increases to $6.4 \mathrm{wt} . \%$, the viscosity of the slag decreases to $0.48 \mathrm{~Pa} \mathrm{~s}$, 
which indicates that the slag has a good fluidity. Further increasing the CaO content to $10.34 \mathrm{wt} . \%$, the viscosity decreases to $0.33 \mathrm{~Pa}$ s. Low-viscosity slag improves the separation of copper from slag while strengthening the erosion and corrosion of the furnace lining, and it shortens the life of the furnace. In addition, Figure 6 depicts the copper content in the slag and slag amount with various $\mathrm{CaO}$ addition. The addition of calcium oxide can reduce the chemically dissolved copper in the slag. Combined with the theory of ion acid-base [25-27], the $\mathrm{Ca}^{2+}$ ion radius is close to the $\mathrm{Cu}^{+}$ion radius, and the $\mathrm{Ca}^{2+}$ would replace part of $\mathrm{Cu}^{+}$in the slag, which reduced the copper content in the slag. Nevertheless, the copper content in the slag has a significant increase after $\mathrm{CaO}$ content is increased to 10.34 wt.\%. Excessive $\mathrm{CaO}$ would lead to an increase in slag amount (Figure 6), while the total copper in the slag increase as a result. Therefore, the amount of calcium oxide added in the slag should be reasonably controlled during the operation. When adding calcium oxide to reduce the viscosity of the slag and the copper content of the slag, the production cost and the slag amount should be considered comprehensively.

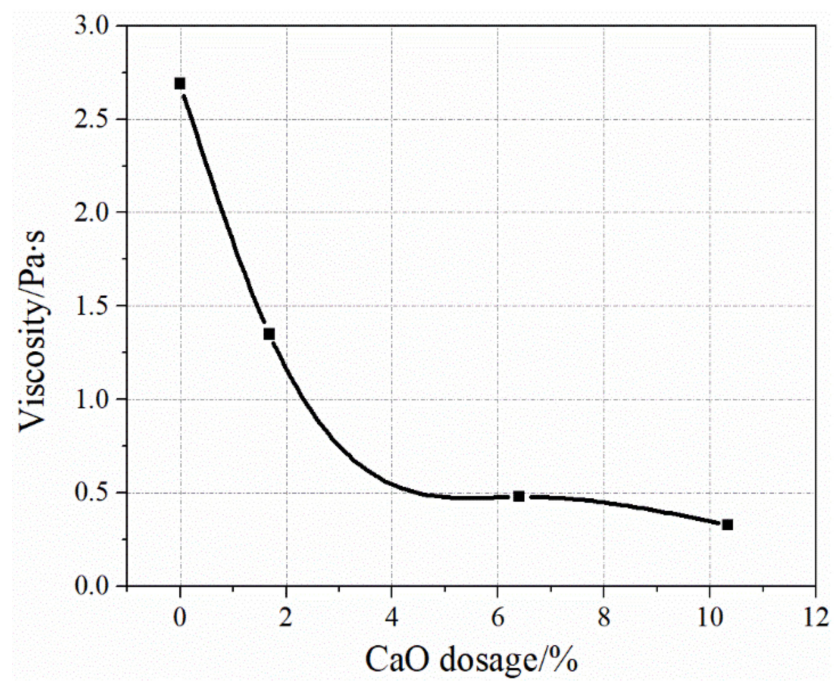

Figure 5. Slag viscosity various with $\mathrm{CaO}$ dosage.

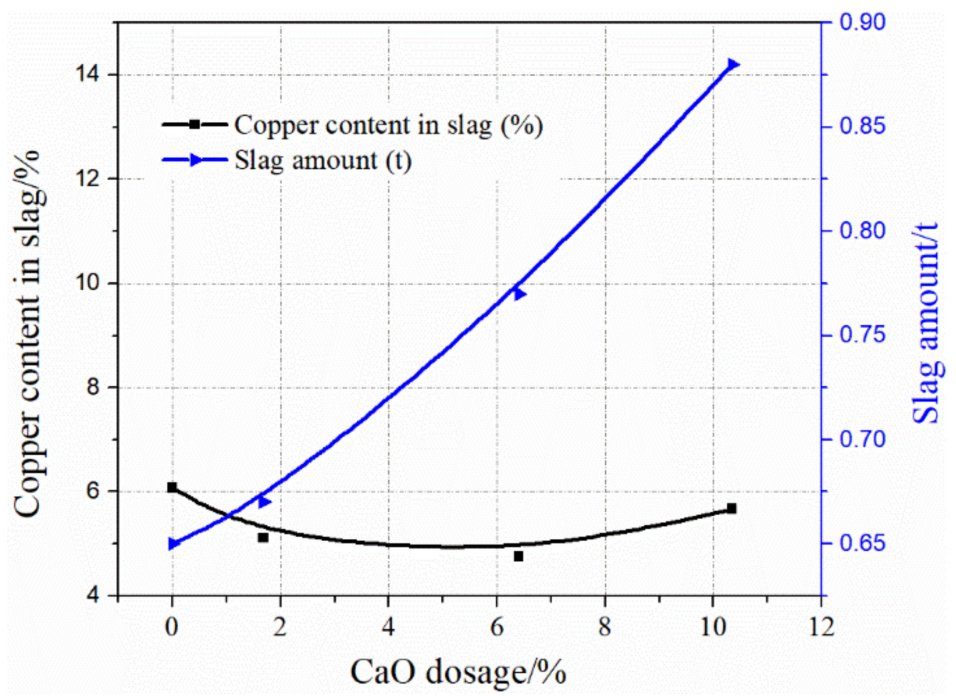

Figure 6. Slag amount and $\mathrm{Cu}$ content in slag viscosity various with $\mathrm{CaO}$ dosage.

Under the conditions of iron-silica ratio $\left(\mathrm{Fe} / \mathrm{SiO}_{2}=0.6\right)$, calcium oxide addition (6.4 wt.\%) and theoretical oxygen consumption (1 $\mathrm{t}$ of raw ore should consume $152.51 \mathrm{~m}^{3}$ of $\mathrm{O}_{2}$ theoretically), the DB copper smelting has been calculated by using equilibrium module of Factsage. The critical process indexes are listed in Table 3. The sulfur content in blister 
is approximately $1.45 \mathrm{wt} . \%$, which brings processing difficulties to subsequent refining due to the high sulfur content. The high sulfur content in the blister may be attributed to oxidation competition between $\mathrm{FeO}$ and $\mathrm{Cu}_{2} \mathrm{~S}$. Thermodynamic calculations show that the standard Gibbs free energy of $\mathrm{FeO}$ oxidation to $\mathrm{Fe}_{3} \mathrm{O}_{4}$ reflects a more negative value than $\mathrm{Cu}_{2} \mathrm{~S}$ oxidation (Figure 7 ), and as the activity of copper sulfide decreases in the later stage, the sulfur in blister copper is more difficult to remove. Therefore, in order to reduce the sulfur content in blister copper, it is necessary to appropriately increase the oxygen supply. Table 3 lists that the sulfur content could be reduced to less than $0.5 \mathrm{wt}$. $\%$ when the oxygen supply exceeds 3.4 vol.\% of the theoretical oxygen. The sulfur content in blister copper should be less than $0.5 \mathrm{wt}$ \% to meet the basic sulfur requirements of blister copper.

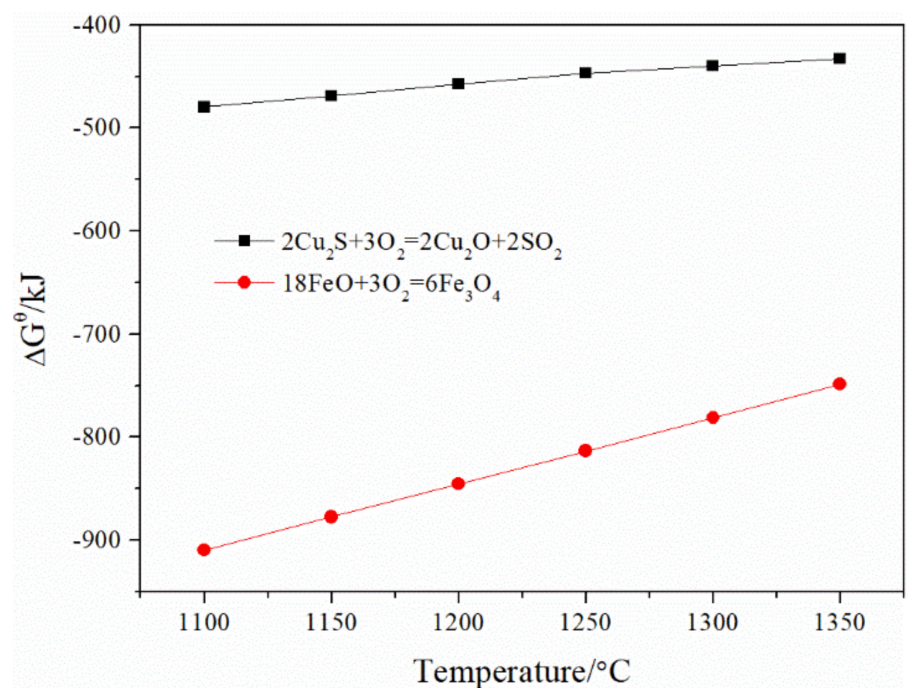

Figure 7. Standard Gibbs free energy of $\mathrm{Cu}_{2} \mathrm{~S}$ and $\mathrm{FeO}$ oxidation reaction.

Table 3. The critical indexes of smelting $1 \mathrm{t}$ of raw ore with $6.4 \% \mathrm{CaO}$ and $0.6 \mathrm{Fe} / \mathrm{SiO}_{2}$ in raw ore at $1300{ }^{\circ} \mathrm{C}$.

\begin{tabular}{ccccc}
\hline $\begin{array}{c}\text { Oxygen } \\
\text { Consumption }\end{array}$ & $\begin{array}{c}\text { Cu Content } \\
\text { in Slag }\end{array}$ & $\begin{array}{c}\text { S Content in } \\
\text { Blister }\end{array}$ & Viscosity & $\begin{array}{c}\text { Slag Amount for } \\
\text { Production of 1 t Blister }\end{array}$ \\
\hline $152.51 \mathrm{~m}^{3}$ & $4.76 \%$ & $1.45 \%$ & $0.48 \mathrm{~Pa} \mathrm{~s}$ & $0.77 \mathrm{t}$ \\
\hline $157.69 \mathrm{~m}^{3}$ & $6.46 \%$ & $0.5 \%$ & $0.49 \mathrm{~Pa} \mathrm{~s}$ & $0.81 \mathrm{t}$ \\
\hline
\end{tabular}

\section{Verification of the Experiment}

Based on the thermodynamic analysis, $80 \mathrm{~g}$ of raw material was smelted at $1300{ }^{\circ} \mathrm{C}$ for $75 \mathrm{~min}$, and the oxygen consumption was 1.034 times the theoretical value. The smelting indexes are listed in Table 4 . The theoretically calculated data are different from the actual experimental results, which are mainly reflected in the copper content in the slag and the copper direct yield. The blister copper grade is reached at $99.09 \mathrm{wt} \%$, and the $S$ in blister copper is $0.61 \mathrm{wt} . \%$, which are in good agreement with the theoretical calculation.

Table 4. The experimental and theoretical smelting indexes.

\begin{tabular}{ccccc}
\hline $\begin{array}{c}\text { Smelting } \\
\text { Parameters }\end{array}$ & $\begin{array}{c}\text { Copper Direct } \\
\text { Yield Rate (\%) }\end{array}$ & $\begin{array}{c}\text { Copper Content } \\
\text { in Slag (wt.\%) }\end{array}$ & $\begin{array}{c}\text { Blister Copper } \\
\text { Grade (wt.\%) }\end{array}$ & $\begin{array}{c}\text { S in Blister } \\
\text { Copper (wt.\%) }\end{array}$ \\
\hline Theoretical value & 93.33 & 6.46 & 99.25 & 0.50 \\
Experimental value & 82.12 & 17.17 & 99.09 & 0.61 \\
\hline
\end{tabular}

Figure 8a shows the images of blister and slag after smelting; the corresponding SEM-EDS and XRD analyses of the slag are also depicted in Figure 8bc. Four phases were 
observed by the $\mathrm{XRD}$ pattern, corresponding to $\mathrm{Cu}, \mathrm{Fe}_{3} \mathrm{O}_{4}, \mathrm{CaMgSi}_{2} \mathrm{O}_{6}$ and $\mathrm{MgFeAlO}_{4}$. In addition, the SEM-EDS analysis also verified the metallic copper, and magnetite phase existed in the slag.
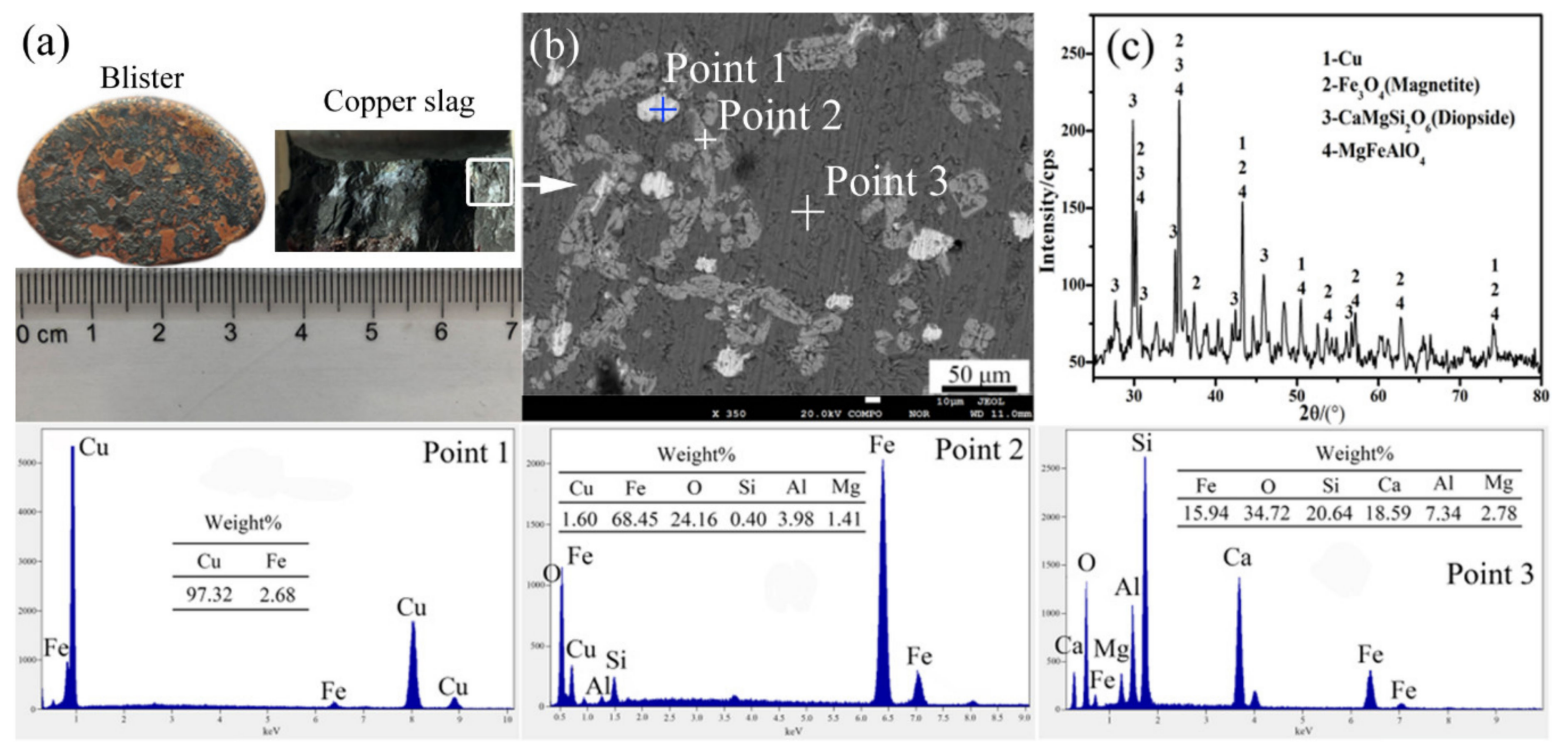

Figure 8. The images of sample after smelting: (a) blister and slag images; (b) SEM analysis of slag; (c) XRD pattern of copper slag.

Theoretical calculation only considered the chemical dissolution loss of copper in the slag, and the copper recovery could reach $93.33 \%$. However, the copper recovery was $82.12 \%$ in the actual smelting process, and the copper content in the slag was up to $17.17 \mathrm{wt} . \%$. The copper loss in the slag is mainly divided into chemical dissolution loss and mechanical entrainment loss. Figure 9 shows the EPMA spectrum of the copper slag; the $\mathrm{Cu}$ existed in the form of metallic. Magnetite particles are gathered around the small copper particles, and a large amount of magnetite distributed in the slag would undoubtedly hinder the settling of copper particles. In addition to the chemical dissolution loss, some mechanically entrained copper particles existed in the slag (Figure 9). This phenomenon causes the copper content in the slag to be higher than the theoretical calculation result (Table 4).

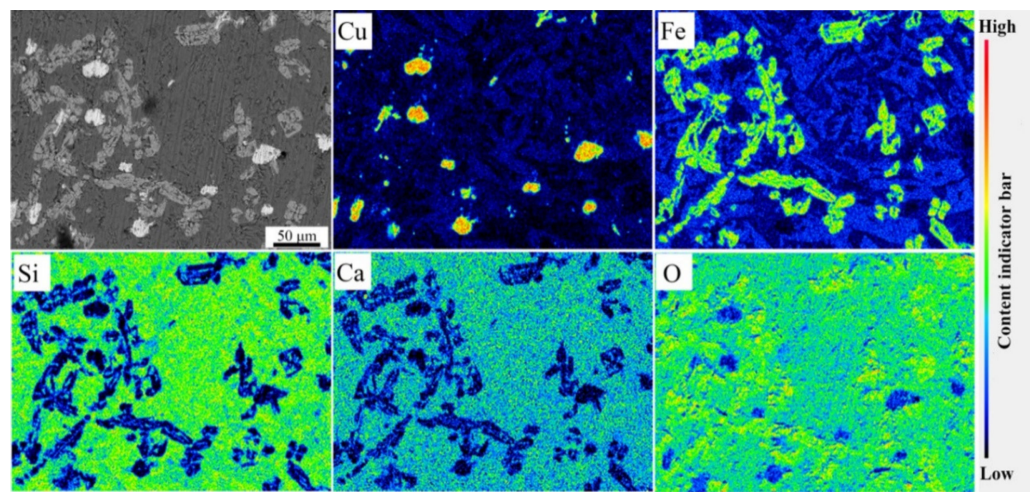

Figure 9. EPMA (Electro-Probe Microanalysis) analysis of slag after smelting at $1300^{\circ} \mathrm{C}$.

\section{Conclusions}

Chalcocite has high copper grade and low iron-silica ratio, and it is suitable for DB copper smelting. Using chalcocite as raw material without adding flux, silica would precipitate in the melt, which is not conducive to the smelting. Theoretical calculations and experimental results indicate that the DB copper smelting of chalcocite can be achieved 
with 0.6 ratio of iron to silica and $6.4 \mathrm{wt} . \% \mathrm{CaO}$ at $1300{ }^{\circ} \mathrm{C}$. The experimental results show that the blister copper grade obtained by DB smelting is approximately $99.09 \mathrm{wt} \%$, and the sulfur content is approximately $0.61 \mathrm{wt} . \%$. It is consistent with theoretical calculation results. The copper content in the slag is higher than the theoretical calculation, and the corresponding copper recovery is $82.12 \%$. The results obtained in present provide theoretical guidance for DB copper smelting of high-grade copper concentrates.

Author Contributions: Conceptualization, S.Z., X.G. and Y.W.; formal analysis, S.Z. and X.G.; writing-original draft, S.Z., X.G. and B.T., writing-review and editing, S.Z., B.L., Y.W. All authors have read and agreed to the published version of the manuscript.

Funding: This research was funded by the National Natural Science Foundation of China (grant number 51974142).

Institutional Review Board Statement: Not applicable.

Informed Consent Statement: Not applicable.

Data Availability Statement: Data sharing not applicable. No new data were created or analyzed in this study. Data sharing is not applicable to this article.

Conflicts of Interest: The authors declare no conflict of interest.

\section{References}

1. Degterov, S.A.; Pelton, A.D. A thermodynamic database for copper smelting and converting. Metall. Mater. Trans. B 1999, 30, 661-669. [CrossRef]

2. Jarosz, P.; Kusiak, J.; Małecki, S.; Morkisz, P.; Oprocha, P.; Pietrucha, W.; Sztangret, Ł. Metamodeling and Optimization of a Blister Copper Two-Stage Production Process. JOM 2016, 68, 1535-1540. [CrossRef]

3. Zhu, Z.Z. Current Copper Metall; Science Press: Beijing, China, 2003.

4. Asteljoki, J.A.; Bailey, L.K.; George, D.B.; Rodolff, D.W. Flash Converting-Continuous Converting of Copper Mattes. JOM 1985, 37, 20-23. [CrossRef]

5. Schmiedl, J.; Holeczy, J.; Sehnalek, F. Continuous production of copper from concentrates. Commun. Soil Plant Anal. 1969, 37, 2461-2469.

6. Wilkomirsky, I.; Parra, R.; Parada, F.; Balladares, E. Continuous Converting of Copper Matte to Blister Copper in a High-Intensity Molten-Layer Reactor. JOM 2014, 66, 1687-1693. [CrossRef]

7. Shibasaki, T.; Hayashi, M. Top-blown injection smelting and converting: The Mitsubishi process. JOM 1991, 43, 20-26. [CrossRef]

8. Kucharski, M.; Sak, T.; Madej, P.; Wedrychowicz, M.; Mróz, W. A Study on the Copper Recovery from the Slag of the Outokumpu Direct-to-Copper Process. Metall. Mater. Trans. B 2014, 45, 590-602. [CrossRef]

9. Mcbow, I.; Kongoli, F.; Tsymbulov, L. Composition and characteristics of slags from continuous converting of copper matte and concentrate. Trans. Inst. Min. Metall. Sect. C Miner. Process. Extr. Metall. 2014, 123, 10-20.

10. Nikolic, S.; Hayes, P.C.; Jak, E. Phase Equilibria in Ferrous Calcium Silicate Slags: Part IV. Liquidus Temperatures and Solubility of Copper in " $\mathrm{Cu}_{2} \mathrm{O}$ "-FeO-Fe ${ }_{2} \mathrm{O}_{3}-\mathrm{CaO}-\mathrm{SiO}_{2}$ Slags at $1250{ }^{\circ} \mathrm{C}$ and $1300{ }^{\circ} \mathrm{C}$ at an Oxygen. Metall. Mater. Trans. B 2008, 39, $210-217$. [CrossRef]

11. Sridhar, R.; Toguri, J.M.; Simeonov, S. Copper losses and thermodynamic considerations in copper smelting. Metall. Mater. Trans. B 1997, 28, 191-200. [CrossRef]

12. Swinbourne, D.R.; West, R.C.; Reed, M.E.; Sheeran, A. Computational thermodynamic modelling of direct to blister copper smelting. Miner. Process. Extr. Metall. 2011, 120, 1-9. [CrossRef]

13. Stefanova, V.; Trifonov, Y. Phase composition of spinel melts obtained during flash smelting of the mineral chalcopyrite. Russ. J. Non-Ferr. Met. 2008, 49, 148-155. [CrossRef]

14. Sun, Y.; Chen, M.; Cui, Z.; Contreras, L.; Zhao, B. Phase Equilibrium Studies of Iron Silicate Slag Under Direct to Blister Copper-Making Condition. Metall. Mater. Trans. B 2019, 51, 1-5. [CrossRef]

15. Sun, Y.; Chen, M.; Cui, Z.; Contreras, L.; Zhao, B. Development of Ferrous-Calcium Silicate Slag for the Direct to Blister Copper-Making Process and the Equilibria Investigation. Metall. Mater. Trans. B 2020, 51, 973-984. [CrossRef]

16. Kongoli, F.; Mcbow, I.; Yazawa, A.; Takeda, Y.; Yamaguchi, K.; Budd, R.; Llubani, S. Liquidus relationships of calcium ferrite and ferrous calcium silicate slag in continuous copper converting. Miner. Process. Extr. Metall. 2008, 117, 67-76. [CrossRef]

17. Yazawa, A. Thermodynamic considerations of copper smelting. Can. Metall. Q. 1974, 13, 443-453. [CrossRef]

18. Yazawa, A.; Takeda, Y.; Nakazawa, S. Ferrous Calcium Silicate Slag to be Used for Copper Smelting and Converting. Proc. Copp. 1999, 6, 587-599.

19. Yazawa, A.; Takeda, Y.; Waseda, Y. Thermodynamic Properties and Structure of Ferrite Slags and Their Process Implications. Can. Metall. Q. 2013, 20, 129-134. [CrossRef] 
20. Somerville, M.; Chen, C.; Alvear, G.R.F.F.; Nikolic, S. Fluxing Strategies for the Direct to Blister Smelting of High Silica and Low Iron Copper Concentrates. In Advances in Molten Slags, Fluxes, and Salts, Proceedings of the 10th International Conference on Molten Slags, Fluxes and Salts, Washington, DC, USA, 22-25 May 2016; John Wiley \& Sons, Ltd: Hoboken, NJ, USA, 2016 ; pp. 667-675.

21. Voigt, P.; Burrows, A.; Somerville, M.; Chen, C. Direct-to-Blister Copper Smelting with the ISASMELT ${ }^{\mathrm{TM}}$ Process. In 8 th International Symposium on High-Temperature Metallurgical Processing; Springer: Cham, Switzerland, 2017; pp. $261-267$.

22. Taskinen, P. Direct-to-blister smelting of copper concentrates: The slag fluxing chemistry. Miner. Process. Extr. Metall. 2011, 120, 240-246. [CrossRef]

23. Taskinen, P.; Kojo, I. Fluxing options in the direct-to-blister copper smelting. In Proceedings of the Molten 2009: VIII International Conference on Molton Slags, Fluxes, and Salts, Santiago, Chile, 18-21 January 2009; pp. 1139-1151.

24. Bale, C.W.; Bélisle, E.; Chartrand, P.; Decterov, S.A.; Eriksson, G.; Gheribi, A.E.; Hack, K.; Jung, I.H.; Kang, Y.B. FactSage thermochemical software and databases, 2010-2016. Calphad 2016, 55, 1-19. [CrossRef]

25. Duffy, J.A.; Ingram, M.D.; Sommerville, I.D. Acid-base properties of molten oxides and metallurgical slags. J. Chem. Soc. Faraday Trans. Phys. Chem. Condens. Ph. 1978, 74, 1410-1419. [CrossRef]

26. Fallah-Mehrjardi, A.; Hayes, P.C.; Jak, E. The Effect of CaO on Gas/Slag/Matte/Tridymite Equilibria in Fayalite-Based Copper Smelting Slags at $1473 \mathrm{~K}\left(1200{ }^{\circ} \mathrm{C}\right)$ and $\mathrm{P}\left(\mathrm{SO}_{2}\right)=0.25 \mathrm{Atm}$. Metall. Mater. Trans. 2018, 49, 602-609. [CrossRef]

27. Kim, H.G.; Sohn, H.Y. Effects of $\mathrm{CaO}, \mathrm{Al}_{2} \mathrm{O}_{3}$, and $\mathrm{MgO}$ additions on the copper solubility, ferric/ferrous ratio, and minor-element behavior of iron-silicate slags. Metall. Mater. Trans. B 1998, 29, 583-590. [CrossRef] 